\title{
Percutaneous CT-Guided Radiofrequency Ablation of Solitary Small Renal Masses: A Single Center Experience
}

\section{Perkutane CT-gesteuerte Radiofrequenz-Ablation von solitären Nierentumoren: Eine Single-Center-Auswertung}

\author{
Authors \\ C. C. Pieper ${ }^{1}$, S. Fischer ${ }^{1}$, H. Strunk ${ }^{1}$, C. Meyer ${ }^{1}$, D. Thomas ${ }^{1}$, W. A. Willinek ${ }^{1}$, S. Hauser ${ }^{2}$, J. Nadal ${ }^{3}$, H. Schild ${ }^{1}$, \\ K. Wilhelm ${ }^{4}$ \\ Affiliations \\ 1 Department of Radiology, University of Bonn, Germany
2 Department of Urology, University of Bonn, Germany
3 Institute for Medical Biometry, Informatics and Epidemiology, University of Bonn, Germany
${ }^{4}$ Department of Radiology, Johanniter GmbH, Johanniter Hospital Bonn, Germany
}

Key words

- abdomen

- urinary

- ablation procedures

- radiofrequency (RF) ablation

received $\quad 19.11 .2014$

accepted 13.2.2015

\section{Bibliography}

Dol http://dx.doi.org/ 10.1055/s-0034-1399340

Published online: 21.4.2015

Fortschr Röntgenstr 2015; 187:

577-583 @ Georg Thieme

Verlag KG Stuttgart · New York . ISSN 1438-9029

\section{Correspondence}

Claus Christian Pieper

Radiologische Klinik,

Universitätsklinik Bonn

Sigmund-Freud-Str. 25

53105 Bonn

Germany

Tel.: ++ 49/2 28/28715237

Fax: ++ 49/2 28/28719083

claus.christian.pieper@ukb.unibonn.de

\section{Zusammenfassung \\ $\nabla$}

Ziel: Analyse der Überlebensraten nach perkutaner CT-gesteuerter Radiofrequenzablation (RFA) von kleinen solitären Nierentumoren in einem Zeitraum von zehn Jahren.

Material und Methoden: Die Patientendaten aller renalen RFAs von 07/2003 bis 11/2013 wurden gesichtet. Die Indikationen zur RFA waren eine bildgebend malignomverdächtige Nierenläsion sowie schwere Komorbiditäten, ein hohes Patientenalter, Vorliegen einer Einzelniere, eine eingeschränkte Nierenfunktion, oder der ausdrückliche Patientenwunsch. Biopsien wurden zum Zeitpunkt der RFA entnommen. Patienten ohne Follow-Up-Untersuchungen wurden von der Auswertung ausgeschlossen. Patienten-bezogene und prozedurale Parameter wurden erfasst. Überlebensraten wurden nach der Kaplan-Meier-Methode berechnet und mittels Log-Rank- bzw. Cox-Test verglichen.

Ergebnisse: Insgesamt wurden 38 Patienten (16 weiblich, mittleres Alter 70,0; 52 -87 Jahre) mit solitären Nierentumoren in die Studie eingeschlossen (Histologie: 29 maligne, 9 benigne Tumoren). Davon litten 26 Patienten an zusätzlichen kardiovaskulären, pulmonalen oder hepatischen Komorbiditäten. 95\% der RFAs waren technisch erfolgreich (komplette Ablation in der ersten Verlaufsuntersuchung). Es wurden 2 Majorkomplikationen (Darmperforation, Hämatothorax) beobachtet. 3- und 7-Jahres-Gesamtüberlebensraten (jede Todesursache) betrugen jeweils $73,4 \pm 0,8 \%$ und 50,3 $\pm 1,0 \%$ (mittleres Follow-up 54,6 [1 127] Monate). Nach RFA wurden 4 Rezidive und 2 neu aufgetretene Metastasen beobachtet. Das Vorliegen von Komorbiditäten war der einzige unabhängige Prädiktor des Gesamtüberlebens. Der Vergleich von Patienten mit benignen und malignen Tumoren ergab keinen signifikanten Unterschied in den Überlebensraten.

Schlussfolgerung: Die RFA von kleinen solitären Nierentumoren ist, bei niedrigen Komplikations-

\section{Abstract \\ $\nabla$}

Purpose: To analyze the outcome of patients undergoing percutaneous CT-guided radiofrequency ablation (RFA) of small renal masses (SRM) at a single center during a ten-year time period.

Materials and Methods: Patient records of renal RFAs (07/2003 - 11/2013) were reviewed. Indications were SRM suspicious of malignancy on imaging and one of the following: severe comorbidity; old age; solitary kidney; impaired renal function; patient wish. Biopsy was performed at the time of RFA. Patients were excluded if no follow-up was available. Patient and procedural characteristics were recorded. Survival rates were calculated using the Kaplan-Meier's method and compared with log-rank or cox tests.

Results: 38 patients (16 females, mean age 70.0 years [range $52-87$ ]) presenting with a solitary SRM were included in the study. Biopsy showed malignancy in 29 patients; 9 had benign tumors. 26 patients suffered from cardiovascular, respiratory or hepatic comorbidities. Technical success (complete ablation on first follow-up) was achieved in $95 \%$ of cases. Two major complications (bowel perforation; hematothorax) occurred. The 3- and 7-year overall survival (OS) [any cause] rates were $73.4 \pm 0.8 \%$ and $50.3 \pm 1.0 \%$, respectively (mean follow-up 54.6 months, range 1 -127). 4 recurrences and 2 metastases were observed. The presence of comorbidities was the only independent predictor of OS. There was no difference in survival between patients with benign and malignant tumors.

Conclusion: RFA of SRM is successful in a large percentage of cases with a low complication rate and durable local control. As RFA is typically performed in multimorbid patients, overall survival seems to depend primarily on comorbidities rather than cancer progression. 
raten, zu einem hohen Prozentsatz technisch erfolgreich und verschafft eine dauerhafte lokale Tumorkontrolle. Das Gesamtüberleben nach RFA hängt bei multimorbiden Patienten primär von Komorbiditäten und weniger vom Tumorprogress ab.

Kernaussagen:

- Die RFA von Nierentumoren hat eine hohe technische Erfolgsrate.

- Durch RFA ist ein hohes Maß an lokaler Tumorkontrolle zu erreichen.

- Nach Therapie versterben die meisten Patienten letztendlich an Komorbiditäten.

- Das Gesamtüberleben nach RFA bei benignen und malignen Tumoren unterscheidet sich bei multimorbiden Patienten nicht.

\section{Introduction}

$\nabla$

Renal cell cancer (RCC) is a common malignant tumor, making up $3 \%$ of all neoplasms with an incidence of 65000 new cases in the USA in 2012 alone [1]. Due to widespread use of cross-sectional imaging, a general increase in the incidence of RCC has been observed over the last decades [2]. Almost $80 \%$ of these tumors are clinically asymptomatic and in a non-metastatic stage [3,4].

Historically radical nephrectomy was the method of choice for curative treatment while nowadays it is primarily partial nephrectomy. However, in some patients surgical management is not feasible because of prior renal surgery, moderate renal failure or severe comorbidities [5]. A select group of patients with increased perioperative risk and $\mathrm{T} 1$ tumors in a parenchymal or exophytic location can be treated with local ablative therapy. Especially percutaneous radiofrequency ablation (RFA) has been established as a treatment option [6]. Several studies have demonstrated the effectiveness of RFA at low complication and recurrence rates $[7,8]$. However, mainly short-term follow-up has been reported and there are still poor data on long-term survival. The objective of this study was to evaluate survival and long-term outcome in patients with an observation period of up to 10 years.

\section{Materials and Methods}

$\nabla$

\section{Patient selection}

Records of all patients who underwent RFA of a small renal mass (SRM) $<4 \mathrm{~cm}$ (one exception with $4.5 \mathrm{~cm}$ ) at our institution (07/ $2003-11 / 2013$ ) were reviewed.

Indications for RFA were the presence of a solitary renal tumor suspicious of malignancy and at least one of the following: severe comorbidity; high patient age ( $>65$ years) associated with higher surgical risk (evaluated by the attending surgeon/urologist); solitary kidney; impaired renal function (chronic kidney disease (CKD) grade $\geq 3 \mathrm{~b}$ according to KDIGO guidelines [9]); explicit patient wish. All patients were evaluated by an urologist and indications were discussed in an interdisciplinary tumor board. Informed consent was obtained from all patients prior to intervention. Patients were excluded from retrospective analysis if no clinical and imaging follow-up examinations were available. The study was carried out in accordance with the code of ethics of the World Medical Association [10].

Contrast-enhanced CT or MRI was performed prior to intervention to assess tumor size and access route in all patients. Biopsies
Key Points

- RFA of SRM is technically successful in the majority of cases.

- RFA leads to a high degree of local tumor control.

- Post-RFA most patients ultimately die of comorbidities.

- Overall survival post-RFA does not significantly differ between benign and malignant tumors in multimorbid patients.

Citation Format:

- Pieper C. C., Fischer S., Strunk H. et al. Percutaneous CT-Guided Radiofrequency Ablation of Solitary Small Renal Masses: A Single Center Experience. Fortschr Röntgenstr 2015; 187: 577-583

were obtained in all cases at the time of RFA via the same access site.

\section{RFA procedure}

All ablations were guided with computed tomography (CT) (Brilliance 16 and 64, Philips Healthcare, The Netherlands) under general anesthesia. Using a trocar, biopsy and ablation were performed in the same session in every case to avoid injection canal metastasis and reduce bleeding complications. Tissue was obtained with a biopsy needle (Quick-Core ${ }^{\circledR}$, Cook Medical, Bloomington, Indiana). Ablation technique and materials were individually chosen using an expandable needle system or a single needle electrode (Le-Veen ${ }^{\circledR}$, Soloist ${ }^{\circledR}$, Boston Scientific, Natick, MA, USA).

\section{Follow-up}

Patients underwent early follow-up examination with contrastenhanced CT or MRI to assess complete ablation of the tumor within two weeks post-RFA. Thereafter a follow-up regime of clinical and imaging examinations at 3-month intervals within the first year, 6-month intervals within the second year, and after that annually was recommended. Enhancement after contrast medium application on CT ( $>15 \mathrm{HU}$ ) or MRI in the previously RF-ablated region was considered as local tumor recurrence.

\section{Data collection, definitions and analysis}

Procedural data, patient characteristics (sex, age, comorbidities, renal function prior to/after RFA, histological findings and tumor size) and results of follow-up examinations were retrospectively reviewed. Procedure-related complications were noted.

The following conditions were defined as relevant comorbidities: severe coronary-artery disease of the main stem or at least two vessels, history of myocardial infarction, congestive heart failure, peripheral arterial disease (Fontaine grade III, IV), history of stroke, chronic obstructive lung disease, liver cirrhosis (Child B, C).

Technical success was defined as complete ablation of the tumor without any residual enhancement in the necrosis area on early imaging follow-up.

The primary study endpoint was overall survival (OS), which was defined as the percentage of patients alive at certain time points (death of any cause). Recurrence-free survival (RFS) was defined as the proportion of patients still alive without local recurrence; disease-free survival (DFS) as the absence of any sign of tumor manifestation (local or metastatic) at the time of the last followup in those patients still alive. 
Survival was analyzed using Kaplan-Meier's method. Significant influence of variables on survival was analyzed using the logrank test for categorical, and the cox test for continuous variables. Multivariate analysis was then performed to identify possible predictors of OS.

Confidence intervals were calculated to compare mean differences of creatinine values as well as estimated GFR (eGFR) before and after RFA to evaluate changes in renal function. eGFR was retrospectively calculated using the Modification of Diet in Renal Disease (MDRD) formula (11) which allows quantification of the eGFR $<60 \mathrm{ml} / \mathrm{min} / 1.73 \mathrm{~m}^{2}$. Higher eGFR values are given as $>60 \mathrm{ml} / \mathrm{min} / 1.73 \mathrm{~m}^{2}$. The chronic kidney disease (CKD) grade prior to and after RFA was additionally determined according to the KDIGO nomenclature (9). Renal function was considered as impaired in grades $\geq 3 \mathrm{~b}$.

\section{Results}

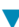

\section{Patient characteristics}

A total of 38 patients ( 16 female, 22 male) suffering from solitary SRM were included in the study. Cross-sectional imaging findings were suspicious of malignancy in all cases. The mean age at the time of RFA was 70.0 years (range $52-87$ years). All patients presented with solid tumors of which nine were benign on histological examination (4 angiomyolipomas, 5 oncocytomas) and 29 were malignant (all RCC). There was no statistically significant difference in mean patient age when comparing those with benign and malignant lesions.

Table 1 Patient characteristics.

Tab. 1 Patientencharakteristika.

\begin{tabular}{|l|l|}
\hline & number \\
\hline patients & $n=38$ \\
\hline male/female & $22 / 16$ \\
\hline mean age at RFA & 70.0 (range $52-87$ ) years \\
\hline comorbidities & \\
\hline cardiovascular and respiratory & $n=23$ \\
\hline hepatic & $n=3$ \\
\hline vHL & $n=2$ \\
\hline histology & \\
\hline malignant & $n=29$ \\
\hline clear cell carcinoma & $n=23$ \\
\hline papillary carcinoma & $n=3$ \\
\hline chromophobe carcinoma & $n=2$ \\
\hline eosinophilic carcinoma & $n=1$ \\
\hline benign & $n=9$ \\
\hline oncocytoma & $n=5$ \\
\hline angiomyolipoma & $n=4$ \\
\hline mean tumor size & 21.0 mm (SD 8.5 mm) \\
\hline solitary kidney/prior nephrectomy & $n=9$ \\
\hline
\end{tabular}

23 patients suffered from cardio-respiratory comorbidities, 3 from severe liver cirrhosis and 2 from a known von-Hippel-Lindau syndrome.

11 patients underwent prior renal surgery due to tumor manifestation ( 7 contralateral total nephrectomies, 2 contralateral total nephrectomies with additional ipsilateral nephron sparing surgery (NSS), 2 ipsilateral NSS). Renal function was impaired in 9 of the patients (CKD grade $\geq 3 \mathrm{~b}$ ). 6 of these 9 patients had undergone contralateral total nephrectomy; the remaining 3 had impaired renal function due to other causes. Patient characteristics are summarized in $\bullet$ Table 1.

\section{Procedural characteristics}

In all patients RFA was performed in a single intervention. Technical success (i. e., complete ablation) was achieved in $36 / 38$ cases $(95 \%)$ with a mean tumor size of $21.0 \mathrm{~mm}( \pm 8.5 \mathrm{~mm})$.

One patient with a well vascularized tumor (RCC) underwent embolization of the tumor with gelfoam particles one day prior to RFA to avoid bleeding complications and to decrease a significant heat-sink effect ( $\bullet$ Fig. 1). In this case diagnostic angiography of the left kidney was performed using a 5-F Cobra-shaped catheter. After identification of tumor-feeding arteries, these were selectively catheterized using a Renegade microcatheter (Boston Scientific, Natick, MA, USA) and a gelfoam slurry was injected. On postinterventional control the tumor-blush was markedly decreased.

The mean time between diagnosis of an SRM suitable for RFA and the date of intervention was 38 days (range 1 - 129 days).

Major complications were observed in two cases (5.1\%). One patient developed bowel perforation following thermal damage in exophytic tumor ablation, although hydro-dissection with glucose solution was performed. In this case immediate surgery and prolonged ICU treatment were necessary. At the end of the follow-up time, the patient was alive and well. In the other case the patient presented with hypotension due to ipsilateral hematothorax on the day post-RFA. The hematothorax was drained with a chest tube and coagulation parameters were normalized. Surgical treatment did not become necessary as the patient stabilized after blood transfusion. There were no late complications. According to CKD grading, renal function deteriorated in 3/38 cases post-RFA. One of these patients developed delayed renal failure during ICU treatment due to bowel perforation. In the other two cases baseline renal function was already impaired prior to RFA. In the remaining 35 patients renal function was stable post-RFA. Overall only minor changes in creatinine values after RFA were observed. In those patients with an eGFR $<60 \mathrm{ml} /$ $\mathrm{min} / 1.73 \mathrm{~m}^{2}(\mathrm{n}=19)$, the mean eGFR changed from $42.23 \mathrm{ml} /$ $\mathrm{min} / 1.73 \mathrm{~m}^{2}$ to $40.55 \mathrm{ml} / \mathrm{min} / 1.73 \mathrm{~m}^{2}$ (० Table 2 ).

\section{Outcome}

Outcome measurements are summarized in $\bullet$ Table 3. Overall 25 patients were alive at the last follow-up examination. One patient died from metastasis of the RCC, while 12 died of other causes.

\begin{tabular}{|lllll|}
\hline & before RFA & after RFA & mean $\Delta$ & Cl \\
\hline creatinine value $[\mathrm{mg} / \mathrm{dl})$ & $1.26(0.36-2.99)$ & $1.38(0.4-4.64)$ & $0.12(0.02-1.94)$ & $-0.016 ; 0.25$ \\
\hline eGFR & & & & \\
\hline$>60 \mathrm{ml} / \mathrm{min} / 1.73 \mathrm{~m}^{2}$ & $\mathrm{n}=19$ & $\mathrm{n}=20$ & & \\
\hline$<60 \mathrm{ml} / \mathrm{min} / 1.73 \mathrm{~m}^{2}$ & $\mathrm{n}=19$ & $\mathrm{n}=18$ & & \\
mean $\left[\mathrm{ml} / \mathrm{min} / 1.73 \mathrm{~m}^{2}\right]$ & $42.23(19.1-59.5)$ & $40.55(13.1-57.4)$ & $-1.68(-15.5-8.7)$ & $-4.58 ; 1.22$ \\
\hline
\end{tabular}

Table 2 Renal function measurements before and after RFA. Cl: confidence interval.

Tab. 2 Nierenfunktionswerte vor und nach RFA. CI: Konfidenzintervall. 

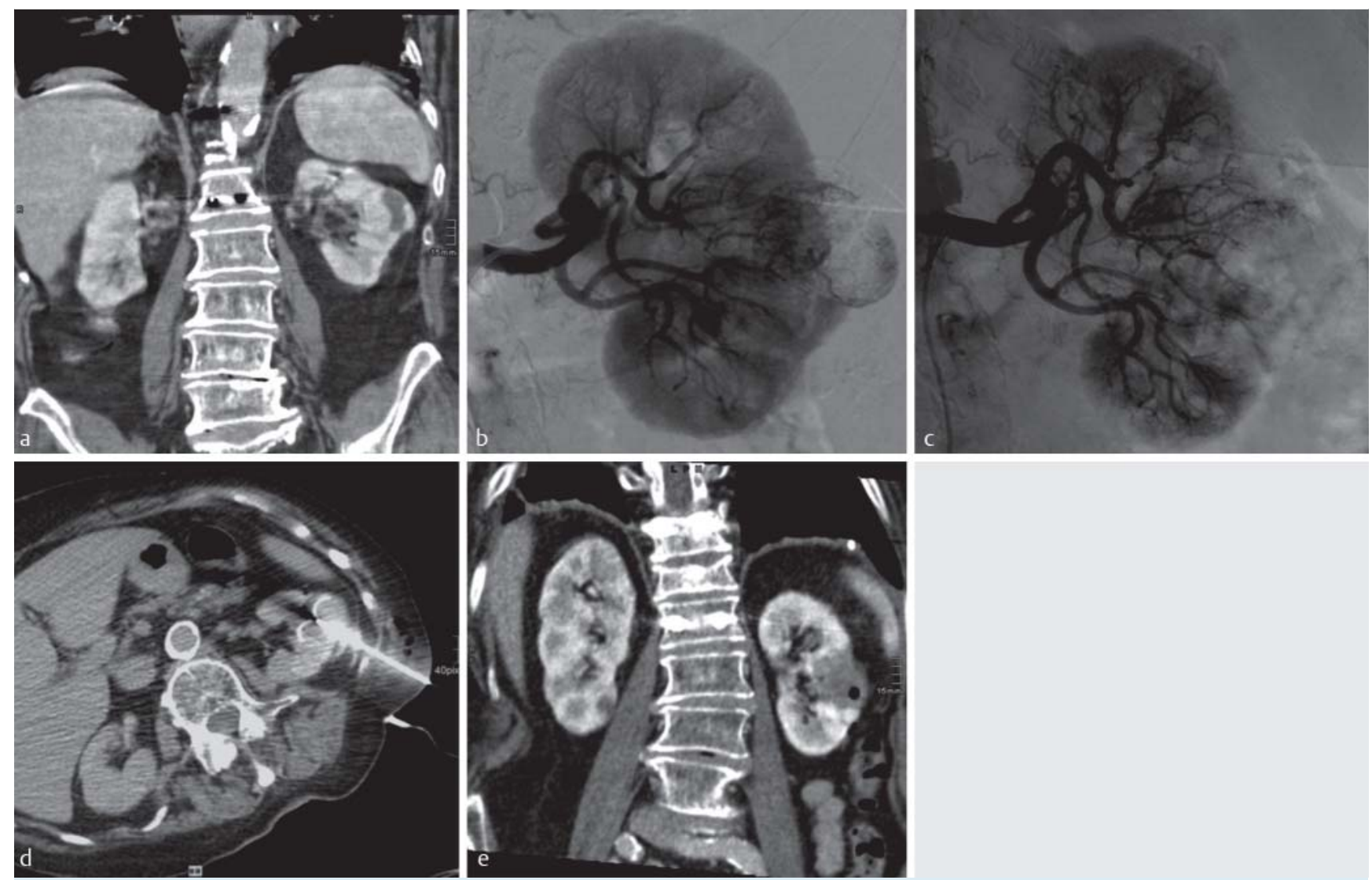

Fig. 1 Case synopsis of an 84 year-old female patient suffering from an exophytic, well-vascularized clear cell RCC of the left kidney (a, frontal CT reconstruction). The patient underwent transarterial embolization of the tumor (b before, and $\mathbf{c}$ after embolization). RFA was performed one day later. $\mathbf{d}$ demonstrates the position of the expandable RFA needle. e shows frontal reconstruction of early follow-up contrast-enhanced CT two weeks after intervention with complete ablation of the tumor.
Abb. 1 Synopse des Falls einer 84 Jahre alten Patientin mit einem exophytisch wachsenden, kräftig vaskularisierten, klarzelligem Nierenzellkarzinom der linken Niere (a, frontale CT-Rekonstruktion). Die Patientin wurde zunächst mittels transarterieller Embolisation des Tumors behandelt (b vor, und c nach Embolisation). Die RFA wurde einen Tag später durchgeführt. d zeigt die Position der RFA-Schirmsonde. e zeigt eine coronale Rekonstruktion des frühen, kontrastverstärkten Verlaufs-CTs zwei Wochen nach Intervention mit kompletter Ablation des Tumors.
The OS after 1,3 , and 7 years for all patients was $88.6 \%( \pm 0.5)$, $73.4 \%( \pm 0.8)$ and $50.3( \pm 1.0)$, respectively. For patients with malignant tumors, the OS after 1,3 and 7 years was $89.0 \%( \pm 0.6)$, $69.0 \%( \pm 0.9)$ and $47.4 \%( \pm 1.2)$, respectively. There was no statistically significant difference between survival in the benign and malignant groups ( $\bullet$ Fig. 2 ). There was also no difference between therapy-naive patients and cases with previous renal surgery ( $\bullet$ Fig. 3).

Four local recurrences were observed ( 3 cases of RCC, 1 angiomyolipoma), with a mean time to recurrence of 25.7 months (range 6-75 months; 75 months in angiomyolipoma). Two local recurrences of RCC were treated with subsequent NSS. In the third case NSS was planned, but due to severe fibrotic and tumoral adhesions the urologist performed total nephrectomy. Recurrence-free survival is given in $\bullet$ Fig. 4.

Two patients developed a metachronous renal tumor outside the ablation zone, both of which were RCCs (time to second tumor 11 and 16.5 months). In one of these patients the new tumor was subsequently treated with total nephrectomy. There was no association between recurrence and incidence of a metachronous renal tumor and von-Hippel-Lindau syndrome (follow-up 54 and 125 months). Two patients with RCC showed new extrarenal metastases to liver and abdominal lymph nodes on follow-up (time to metastases 9 and 13.5 months). Overall 4 patients were fol- lowed-up for more than 10 years ( 2 cases of RCC, 2 angiomyolipomas) and are alive and well.

Univariate analysis showed that OS depended significantly on tumor size $(p=0.049)$ and the presence of cardio-respiratory as well as hepatic comorbidities $(\mathrm{p}=0.008)$ ( $\bullet$ Fig. 5). All other variables (sex, age, complete ablation, histology, occurrence of major complications, previous surgery, recurrences, extrarenal metastases, metachronous tumors) had no significant effect on the OS. Multivariate analysis showed the presence of comorbidities to be the only independent predictor of OS $(p=0.027)$. Likewise univariate analysis showed that RFS and DFS depended on the presence of comorbidities only ( $\mathrm{p}=0.05, \mathrm{p}=0.036)$.

\section{Discussion}

$\nabla$

Radical nephrectomy has long been the standard therapy for RCC [12], but in recent years several nephron-sparing approaches have been developed to preserve renal function [13, 14]. However, NSS can be burdened with considerable perioperative morbidity and mortality because of high age and comorbidities of the patients. NSS therefore was recently shown to be less commonly utilized in this patient collective [15]. In cases of low life expectancy and considering low rates of metastases in low grade SRM, 
Table 3 Outcome measurements.

Tab. 3 Outcome der Patienten.

\begin{tabular}{|c|c|c|}
\hline & all & malignant \\
\hline mean follow-up & $\begin{array}{l}54.6 \text { months } \\
\text { (range } 1-127 \\
\text { months) }\end{array}$ & $\begin{array}{l}50.5 \text { months } \\
\text { (range } 1-127 \\
\text { months) }\end{array}$ \\
\hline technical success & $36 / 38$ & $27 / 29$ \\
\hline $\begin{array}{l}\text { major complica- } \\
\text { tions }\end{array}$ & $2 / 38$ & $1 / 29$ \\
\hline recurrence & $N=4$ & $N=3$ \\
\hline $\begin{array}{l}\text { extra-renal } \\
\text { metastases }\end{array}$ & $N=2$ & $N=2$ \\
\hline new renal tumor & $N=2$ & $N=2$ \\
\hline $\begin{array}{l}\text { death related to } \\
\text { tumor }\end{array}$ & $\mathrm{N}=1(1 \mathrm{RCC})$ & 1 (1 RCC) \\
\hline overall survival & $\%(S D) /$ patients at risk & $\%(S D) /$ patients at risk \\
\hline 1 year & $88.6(0.5) / n=31$ & $89.0(0.6) / n=24$ \\
\hline 3 years & $73.4(0.8) / n=21$ & $69.0(0.9) / n=15$ \\
\hline 7 years & $50.3(1.0) / n=10$ & $47.4(1.2) / n=6$ \\
\hline \multicolumn{3}{|c|}{ recurrence-free survival } \\
\hline 1 year & $77.3(0.7) / n=27$ & $74.3(0.8) / n=20$ \\
\hline 3 years & $67.6(0.8) / n=19$ & $61.5(1.0) / n=13$ \\
\hline 7 years & $39.9(1.0) / n=8$ & $39.9(1.2) / n=5$ \\
\hline \multicolumn{3}{|c|}{ disease-free survival } \\
\hline 1 year & $77.3(0.7) / n=27$ & $74.3(0.8) / n=20$ \\
\hline 3 years & $67.2(0.8) / n=18$ & $60.7(1.0) / n=12$ \\
\hline 7 years & $37.6(1.0) / n=7$ & $36.4(1.3) / n=4$ \\
\hline
\end{tabular}

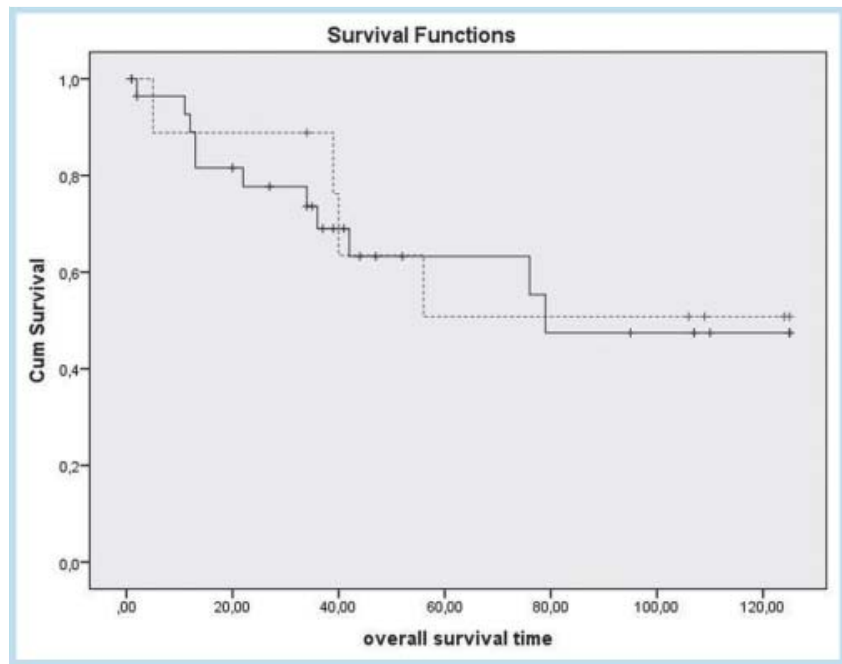

Fig. 2 Kaplan-Meier curve: overall survival in months by histology. Broken line: benign, continuous line: malignant tumors.

Abb.2 Kaplan-Meier-Kurve: Gesamtüberleben in Monaten getrennt nach Histologie. Gestrichelte Linie: benigne; durchgezogene Linie: maligne Tumoren.

active surveillance has been suggested as an alternative [16]. However, tumor size alone is known to be an unreliable predictor of tumor grade [17]. This fact and often also patient wish to receive treatment led to the development of alternative, minimally invasive treatment options.

Radiofrequency ablation of SRM has emerged as a widely used technique to achieve local tumor control in curative intent [1, 18]. Oncological effectiveness of RFA in RCC treatment has been demonstrated in several studies with cancer-specific survival

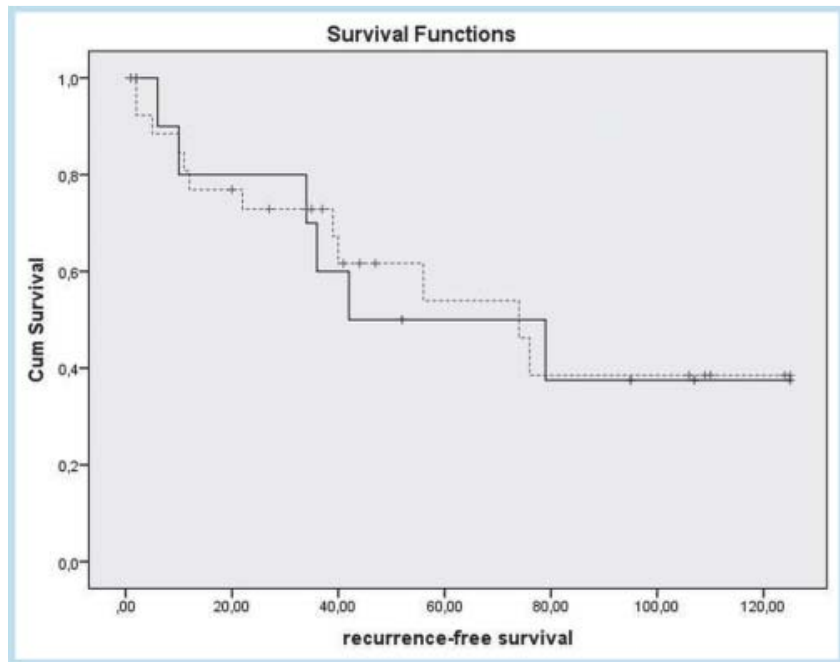

Fig. 3 Kaplan-Meier curve: recurrence-free survival in months by previous renal surgery. Broken line: no previous surgery, continuous line: history of previous surgery.

Abb.3 Kaplan-Meier-Kurve: Rezidiv-freies Überleben in Monaten getrennt nach stattgehabter Nierenoperation. Gestrichelte Linie: keine vorhergehende OP; durchgezogene Linie: vorhergehende OP.

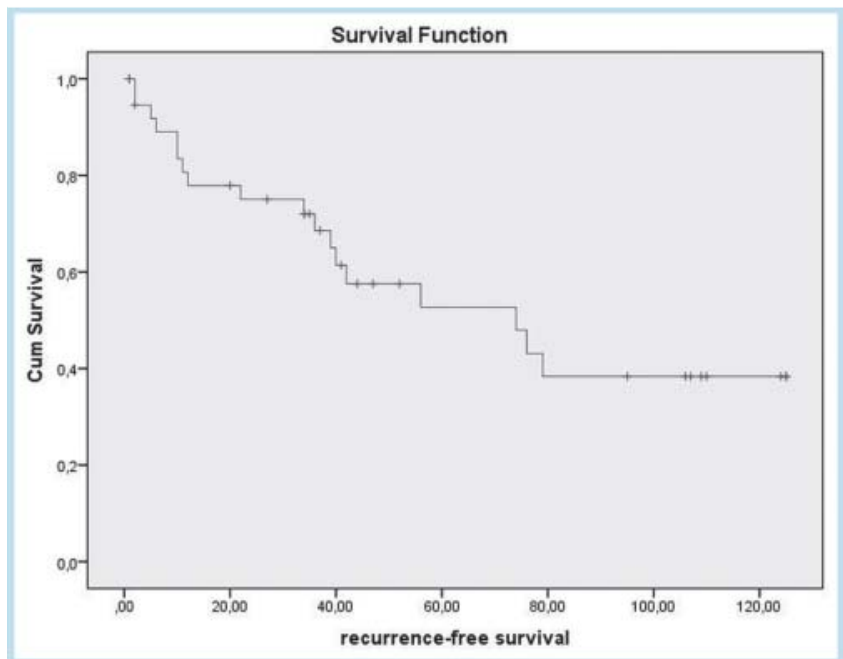

Fig. 4 Kaplan-Meier curve: recurrence-free survival in months.

Abb.4 Kaplan-Meier-Kurve: Rezidiv-freies Überleben in Monaten.

rates comparable to partial nephrectomy [7, 8]. 5-year OS rates of $73-85 \%$ have been described in the largest studies on RFA of RCC $<4 \mathrm{~cm}$ so far $[19,20]$. All local recurrences reported in one study (9/243 cases) occurred within the first 3 years after ablation [19], which is in accordance with our data.

However, most available studies only reported short-term or mid-term follow-up $[7,8,19,20]$. Only recently there have been first studies reporting longer follow-up [20, 22]. Overall, the number of patients reported in the literature with a follow-up of longer than 5 years is still rather limited.

The aim of this study was therefore to report our experiences with RFA for SRM performed at our institution over a time period of 10 years. 


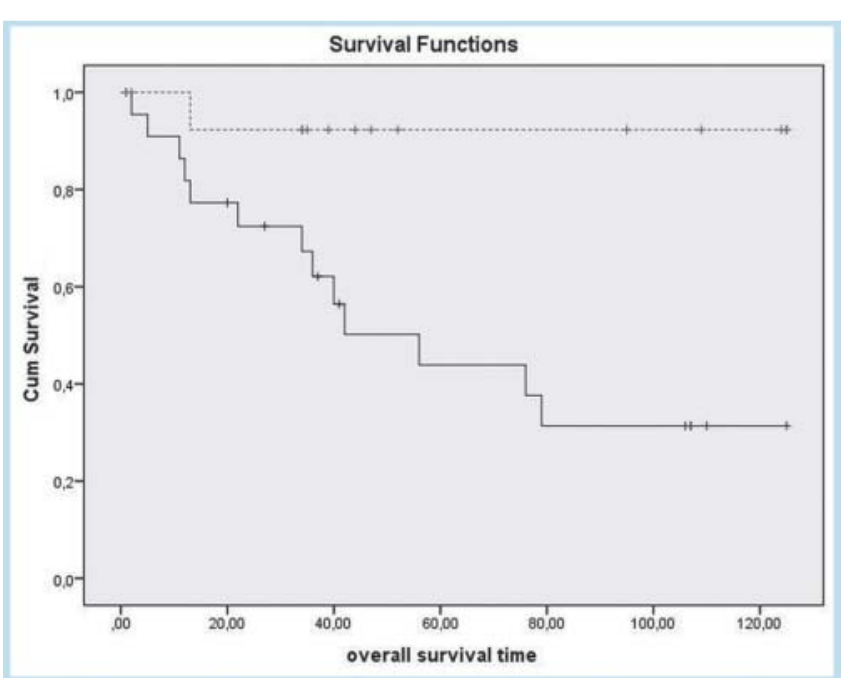

Fig. 5 Kaplan-Meier curve: overall survival in months by presence of comorbidity. Broken line: no comorbidities, continuous line: at least one comorbidity.

Abb.5 Kaplan-Meier-Kurve: Gesamtüberleben in Monaten getrennt nach Vorliegen von Komorbiditäten. Gestrichelte Linie: keine Komorbiditäten; durchgezogene Linie: mindestens eine Komorbidität.

Our results demonstrate that RFA of SRM $<4 \mathrm{~cm}$ is technically successful in the majority of cases with a low complication rate. Two major complications were observed. This is in line with previously described complication rates of $4-6 \%[22,23]$ and comparable to those observed in open partial nephrectomy (4.5$8.7 \%$ ) [24]. In one case thermal damage led to bowel perforation with the need of immediate surgery and prolonged ICU treatment. This is a known complication of renal RFA, especially in exophytic tumors. To protect critical structures, the distance to the ablation zone can be increased via hydro- or $\mathrm{CO}_{2}$-dissection which also provides insulation [25]. However, in our case thermal damage was observed despite hydro-dissection with glucose solution.

We observed stable renal function after RFA in $92 \%$ of patients on follow-up. In one case delayed worsening of renal function was related to complications following bowel perforation. On average a decrease of about $5 \%$ of eGFR can be expected after RFA of a single tumor, depending on tumor size (3.8 - 14.5\%) [26]. In patients with an eGFR $<60 \mathrm{ml} / \mathrm{min} / 1.73 \mathrm{~m}^{2}$, we observed a minor drop in eGFR values by $1.68 \mathrm{ml} / \mathrm{min} / 1.73 \mathrm{~m}^{2}$. As already described, this lack of renal function impairment represents one of the major advantages of RFA compared to nephrectomy which is associated with a median drop in renal function by $29 \%$ [27 - 29].

As we performed biopsy of the suspicious renal lesion only immediately prior to intervention, RFA was performed regardless of the results of histological examination. This led to a proportion of $24 \%$ benign tumors being included in the current series. This is in line with published results from surgically resected SRM with a mean percentage of $15 \%$ (range 7 - $33 \%$ ) benign tumors, especially in T1a lesions [30]. It is a known problem that preinterventional imaging has poor predictive values concerning differentiation of benign vs. malignant SRM with as little as $17 \%$ of benign lesions being diagnosed correctly on CT [31, 32].
Survival was not significantly different between the group with benign and malignant lesions, reflecting the high rate of local control of malignant tumors after RFA.

It has been described that disease-free survival after RFA is significantly associated with tumor stage (T1a, T1b) with a 5-year DFS rate of $91.5 \%$ for T1a RCC and $74.5 \%$ for T1b RCC [20]. In our study all patients but one suffered from a renal tumor $<4 \mathrm{~cm}$. Although there were no large differences in tumor size in our patient group, the OS was significantly associated with the tumor diameter in univariate analysis.

Cancer-associated death was only observed in one case (RCC). The majority of patients died of other causes. Although the Charlson Comorbidity Index was found not to be associated with survival in one report [20], we found that the OS significantly depended on the presence of comorbidities (respiratory, cardiovascular or hepatic). Multivariate analysis even demonstrated the presence of comorbidities to be the only independent predictor of OS in our collective.

The occurrence of a second renal tumor has been described in 3 $5 \%$ of cases [33], which is comparable to our experiences with metachronous tumors in $5 \%$ of cases. It is important to note that both patients with second tumor development did not suffer from von-Hippel-Lindau syndrome, which is commonly associated with the development of multiple tumors [34].

We observed two cases with new metastatic disease after RFA (metastases to the liver and lymph nodes). Only one patient died due to progressive metastatic RCC. Similarly a percentage of only $3.9 \%$ of patients who died of metastatic disease after partial nephrectomy has been reported [35]. It cannot be ruled out that these patients already had micrometastases at the time of RFA [20].

There are several limitations of the present study. First, the analysis was conducted retrospectively in a relatively small number of patients. Especially the patient group with benign tumors was rather small. Secondly, the cohort under investigation was rather heterogenic, including both benign and malignant lesions. In addition, as the data reflect 10 years of experience of a single center, bias due to a learning curve and experience of different radiologists in RFA of SRM cannot be excluded.

In conclusion, the presented results add to the limited long-term data after RFA of SRM, indicating that RFA allows for a high rate of local tumor control in older and especially multimorbid patients. Statistical analysis showed that most patients ultimately died of other causes associated with their respective comorbidities. The complication rate of RFA was low, making it an alternative to more invasive surgery or active surveillance, especially in patients with the desire for treatment.

\section{Clinical Relevance of the Study}

- Percutaneous CT-guided RFA of SRM is a feasible alternative to surgery or active surveillance with a high rate of technical success and low complication rates in a multimorbid patient cohort.

- Durable local tumor control can be achieved in the majority of cases.

- When performed in a multimorbid patient cohort, RFA results in most patients ultimately dying of other causes associated with their comorbidities. 


\section{References}

1 Georgiades C, Rodriguez R. Renal tumor ablation. Tech Vasc Interv Radiol 2013; 16: 230-238

2 Volpe A, Panzarella T, Rendon RA et al. The natural history of incidentally detected small renal masses. Cancer 2004; 100: 738-745

3 Bosniak MA, Birnbaum BA, Krinsky GA et al. Small renal parenchymal neoplasms: further observations on growth. Radiology 1995; 197: 589-597

4 Homma Y, Kawabe K, Kitamura $T$ et al. Increased incidental detection and reduced mortality in renal cancer-recent retrospective analysis at eight institutions. Int J Urol 1995; 2: $77-80$

5 O'Malley RL, Hayn MH, Hellenthal NJ et al. Safety and outcomes of surgical treatment of renal cell carcinoma in the elderly. Can J Urol 2012; 19: $6111-6117$

6 Campbell SC, Novick AC, Belldegrun A et al. Practice Guidelines Committee of the American Urological Association. Guideline for management of the clinical T1 renal mass. J Urol 2009; 182: 1271-1279

7 Stern JM, Svatek R, Park S et al. Intermediate comparison of partial nephrectomy and radiofrequency ablation for clinical T1a renal tumours. BJU Int 2007; 100: 287-290

8 Park S, Strup SE, Saboorian $H$ et al. No evidence of disease after radiofrequency ablation in delayed nephrectomy specimens. Urology 2006; 68: 964-967

9 National Kidney Foundation. KDIGO 2012 Clinical Practice Guideline for the Evaluation and Management of Chronic Kidney Disease. Kidney International Supplements 2013; 3: 136-150

10 World Medical Association. World Medical Association Declaration of Helsinki: ethical principles for medical research involving human subjects. JAMA 2013; 310: $2191-2194$

11 Levey AS, Juan P, Bosch JD et al. for the Modification of Diet in Renal Disease Study Group: A More Accurate Method To Estimate Glomerular Filtration Rate from Serum Creatinine: A New Prediction Equation. Ann Intern Med 1999; 130: 461 - 470

12 Robson CJ, Churchill BM, Anderson W. The results of radical nephrectomy for renal cell carcinoma. J Urol 1969; 101: 297- 301

13 Lane BR, Gill IS. 7-year oncological outcomes after laparoscopic and open partial nephrectomy. J Urol 2010; 183: 473-479

14 Uzzo RG, Novick AC. Nephron sparing surgery for renal tumors: indications, techniques and outcomes. J Urol 2001; 166: 6-18

15 Baillargeon-Gagné S, Jeldres C, Lughezzani G et al. A comparative population-based analysis of the rate of partial vs radical nephrectomy for clinically localized renal cell carcinoma. BJU Int 2010; 105: 359-364

16 Thompson RH, Kurta JM, Kaag M et al. Tumor size is associated with malignant potential in renal cell carcinoma cases. J Urol 2009; 181: 2033 2036

17 Hsu RM, Chan DY, Siegelman SS. Small renal cell carcinomas: correlation of size with tumor stage, nuclear grade, and histologic subtype. Am J Roentgenol Am J Roentgenol 2004; 182: 551 - 557

18 Tracy CR, Raman JD, Donnally C et al. Durable oncologic outcomes after radiofrequency ablation: experience from treating 243 small renal masses over 7.5 years. Cancer $2010 ; 116$ : $3135-3142$
19 Tacke J, Mahnken AH, Günther RW. Percutaneous thermal ablation of renal neoplasms. Rofo 2005; 177: 1631 - 1640

20 Psutka SP, Feldman AS, McDougal WS et al. Long-term oncologic outcomes after radiofrequency ablation for T1 renal cell carcinoma. Eur Urol 2013; 63: 486-492

21 Zagoria RJ, Pettus JA, Rogers $M$ et al. Long-term outcomes after percutaneous radiofrequency ablation for renal cell carcinoma. Urology 2011; 77: $1393-1397$

22 Balageas P, Cornelis F, Le Bras $Y$ et al. Ten-year experience of percutaneous image-guided radiofrequency ablation of malignant renal tumours in high-risk patients. Eur Radiol 2013; 23: 1925-1932

23 Hiraoka K, Kawauchi A, Nakamura T et al. Radiofrequency ablation for renal tumors: our experience. Int J Urol 2009; 16: 869-873

24 Hui GC, Tuncali K, Tatli S et al. Comparison of percutaneous and surgical approaches to renal tumor ablation: metaanalysis of effectiveness and complication rates. J Vasc Interv Radiol 2008; 19: 1311-1320

25 Tsoumakidou G, Buy X, Garnon J et al. Percutaneous thermal ablation: how to protect the surrounding organs. Tech Vasc Interv Radiol 2011; 14: $170-176$

26 Gupta P, Allen BC, Chen MY et al. Renal function outcomes for multifocal renal neoplasms managed by radiofrequency ablation. Cardiovasc Intervent Radiol 2013; 36: 1329-1335

27 Pettus JA, Werle DM, Saunders $W$ et al. Percutaneous radiofrequency ablation does not affect glomerular filtration rate. J Endourol 2010; 24: $1687-1691$

28 Cornelis F, Buy X, Andre $M$ et al. De novo renal tumors arising in kidney transplants: midterm outcome after percutaneous thermal ablation. Radiology 2011; 260: 900-907

29 Corcoran AT, Russo P, Lowrance WT et al. A review of contemporary data on surgically resected renal masses-benign or malignant? Urology 2013; 81: 707-713

30 Millet I, Doyon FC, Hoa D et al. Characterization of small solid renal lesions: can benign and malignant tumors be differentiated with CT? Am J Roentgenol Am J Roentgenol 2011; 197: 887-896

31 Remzi M, Katzenbeisser D, Waldert M et al. Renal tumour size measured radiologically before surgery is an unreliable variable for predicting histopathological features: benign tumours are not necessarily small. BJU Int 2007; 99: $1002-1006$

32 Grimaldi G, Reuter V, Russo P. Bilateral non-familial renal cell carcinoma. Ann Surg Oncol 1998; 5: 548-552

33 Maher ER, Yates JR. Familial renal cell carcinoma: clinical and molecular genetic aspects. Br J Cancer 1991; 63: 176-179

34 Minardi D, Lucarini G, Mazzucchelli R et al. Prognostic role of Fuhrman grade and vascular endothelial growth factor in pT1a clear cell carcinoma in partial nephrectomy specimens. J Urol 2005; 174: 1208-1212

35 Takaki H, Yamakado K, Soga $\mathrm{N}$ et al. Midterm results of radiofrequency ablation versus nephrectomy for T1a renal cell carcinoma. Jpn J Radiol 2010; 28 : $460-468$ 